\title{
Differences in Anthropometric Characteristics among Junior Basketball and Volleyball Players
}

\author{
Yusuf Can Pasa', Velisa Vukasevic ${ }^{2}$, Bojan Masanovic ${ }^{3}$ \\ 'Pamukkale University, Faculty of Sport Sciences, Denizli, Turkey, ${ }^{2}$ Basketball Club Vizura, Belgrade, Serbia, ${ }^{3}$ University of Montenegro, Faculty for \\ Sport and Physical Education, Niksic, Montenegro
}

\begin{abstract}
The aim of this study was to obtain the relevant knowledge about significant differences in some anthropometric characteristics of junior basketball and voleyball players. The sample included 27 male subjects divided into two subsamples. The first subsample included 13 subjects, who train in the junior selection in the Basketball club Vojvodina from Novi Sad, while the other subsample included 14 subjects who train in the junior selection in the Voleyball club Vojvodina, from Novi Sad. The variables sample included 20 anthropometric measures that defined longitudinal and transversal dimensionality of skeleton, volume and mass of the body, and subcutaneous adipose tissue. The results were analysed in a statistical procedure marked as a significance testing of two arithmetic means of the independent samples, a t-test at the level of significant of $p<0.05$. It was concluded, based on these results, that significant differences do not occur even for one of the 20 measured variables.
\end{abstract}

Key words: Anthropometric Measurement, Different Sports, Junior League

\section{Introduction}

Understanding the morphological characteristics is considered as an essential part of the total management process (Popovic, Bjelica, Jaksic, \& Hadzic, 2014; Bjelica i Fratric, 2011). The need to investigate the anthropometrical characteristics numbers of basketball and volleyball players is important, because among other factors, contribute to optimal exercise routines and performance (Spaic, Vukasevic, \& Masanovic, 2018). It is widely known in the scientific literature that adequate profiles are primarily important in various sports, mostly due to the reason that absolute size contributes a significant percentage of total variance associated with athletic success (Rađa, Erceg, \& Grgantov, 2016; Vukotic, 2018). According to previous studies, successful participation in both basketball and volleyball games, requires not only a high level of technical and tactical skills, but also suitable anthropometrical characteristics and body composition from each athlete (Monson, Brasil, \& Hlusko, 2018; Hurst et al., 2017; Pojskic, Separovic, Muratovic, \& Uzicanin, 2014; Masanovic, Spaic, \& Vukasevic, 2018). In sports like basketball and volleyball, players tend to be tall because they handle a ball above their heads (Popovic et al., 2013; Popovic et al., 2014). Muscle-skeletal mass is an indicator of sports performance, because it contributes to the energy production during high-intensity activities and provides absolute strength to athletes. On the contrary, excessive fat mass compromises the physical performance, acts as a dead body mass in activities where the body must be repeatedly lifted during motion and jumping, decreasing performance and increasing energy demands (Ramos-Campo et al., 2014; Bjelica, Popovic, \& Gardasevic, 2016; Masanovic, Milosevic, \& Corluka, 2018). Mentioned facts acknowledge that profesionaly engaging with basketball and volleyball beside high level of tehnical and tactical skills and high level of atletic abilities it is necessary to have certain anthropomtric characteristics.

Basketball is considered an acyclic sports game, with extremely complex movements, specific and functional characteristics, defining it as anaerobic-glycotic activity, characterized with a large number of repetitive explosive-velocity moving structures, of extremely high intensity. Due to the constant changes in the intensity of movement, which is manifested through different offensive and defensive situations, the average intensity of basketball players during the compe-

\section{Correspondence:}

Montenegro Sport

\section{B. Masanovic}

University of Montenegro, Faculty for Sport and Physical Education, Niksic, Montenegro

E-mail: bojanma@ucg.ac.me 
tition game is above $85 \%$ of the maximal heart rate and above $80 \%$ of BO 2 max (Spaic et al., 2018; Stojanovic et al., 2016). In this game, the patterns of movement differ greatly compared to volleyball, the basic elements of the game are spiking, jumping, power hitting and blocking. In vooleyball the dominance over the net becomes the most decisive factor for victory. The top-level volleyball players do not have $\mathrm{VO} 2$ max values on the high level as endurance trained elite players in basketball.

The aim of these studies is to describe the morphological profile of young basketball and volleyball players, to determine if there is a difference in anthropometric dimensions between them, and to define its scale.

\section{Method}

The sample included 27 male subjects divided into two subsamples. The first subsample included 13 basketball players $(17.08 \pm 0.28 \mathrm{yrs}$.), who trained in the junior selection in the Basketball club "Vojvodina" from Novi Sad, which competed in Serbian Junior League, while the other subsample included 14 volleyball plajers (17.36 \pm 0.74 yrs.), who trained in the junior selection in the Volleyball club "Vojvodina" from Novi Sad, which also competed in Serbian Junior League. Criteria for selection of subjects for the sample were as follows: they have been members of the first team squad for at least one year and that they are in good health.

Anthropometric research technique was used for data collection. A total of 20 anthropometric measures were evaluated which defined the longitudinal and transversal dimensionality of skeleton, body volume and body mass, and subcutaneous adipose tissue: body height, body weight, elbow diameter, wrist diameter, knee diameter, ankle joint diameter, minimum circumference of the upper arm, maximum circumference of the upper arm, minimum circumference of the forearm, maximum circumference of the forearm, minimum circumference of the upper leg, maximum circumference of the upper leg, minimum circumference of the lower leg, maximum circumference of the lower leg, skinfold thickness of the upper arm, skinfold thickness of the forearm, skinfold thickness of the thigh, skinfold thickness of the calf, skinfold thickness of the chest and skinfold thickness of the abdomen.

Anthropometric research was conducted according to IBP standards, while respecting the basic rules and principles related to the selection of parameters, standard conditions and measuring techniques, as well as the standard measuring instruments calibrated before measuring.

The measuring was carried out in the middle of a competitive season. The data obtained in the research were analyzed with the statistical program SPSS 20.0, adapted for use on personal computers. The arithmetic mean, standard deviation and standard errors of the arithmetic mean of the anthropometric characteristics were calculated for respondents who are professional basketball players and professional volleyball players, by testing the differences of arithmetic means of independent samples at a significance level of $p<0.05$. This analysis proved that there is a difference, and the scope of it, between the anthropometric characteristics of the basketball and volleyball players, regulars who compete in union divisions.

\section{Results}

This section presents the results of central tendency and dispersion parameters, as well as the results of t-test for independent samples, classified into tables. Observing the results of the central tendency and dispersion parameters of longithudinal and transversal skeletal dimensionality, body volume and body mass of the basketball and volleyball players, we immediately notice that volleyball players have higher value in 11 variables, while in terms of basketballers, have higher values in 9 variables (Table 1 ).

Table 1. Descriptive Statistics

\begin{tabular}{lcc}
\hline & $\begin{array}{c}\text { Basketball (13) } \\
\text { MEAN } \pm \text { SD }\end{array}$ & $\begin{array}{c}\text { Volleyball (14) } \\
\text { MEAN } \pm \text { SD }\end{array}$ \\
\hline Body height $(\mathrm{cm})$ & $193.60 \pm 7.69$ & $194.28 \pm 5.30$ \\
Bodyweight $(\mathrm{kg})$ & $80.00 \pm 9.75$ & $82.04 \pm 8.58$ \\
Elbow diameter $(\mathrm{mm})$ & $73.87 \pm 2.55$ & $75.69 \pm 3.85$ \\
Wrist diameter $(\mathrm{mm})$ & $60.73 \pm 2.48$ & $59.69 \pm 3.71$ \\
Knee diameter $(\mathrm{mm})$ & $99.24 \pm 4.74$ & $97.81 \pm 4.79$ \\
Ankle joint diameter $(\mathrm{mm})$ & $73.61 \pm 2.66$ & $74.00 \pm 3.00$ \\
Upper arm circumference $(\min )(\mathrm{cm})$ & $28.96 \pm 1.74$ & $28.68 \pm 1.88$ \\
Upper arm circumference $(\max )(\mathrm{cm})$ & $30.84 \pm 1.86$ & $30.57 \pm 1.88$ \\
Lower arm circumference $(\min )(\mathrm{cm})$ & $17.11 \pm 0.92$ & $16.82 \pm .70$ \\
Lower arm circumference $(\mathrm{max})(\mathrm{cm})$ & $26.00 \pm 1.38$ & $25.72 \pm 1.44$ \\
Upper leg circumference $(\min )(\mathrm{cm})$ & $39.81 \pm 2.80$ & $40.90 \pm 2.30$ \\
Upper leg circumference $(\max )(\mathrm{cm})$ & $55.11 \pm 3.95$ & $56.11 \pm 3.36$ \\
Lower leg circumference $(\min )(\mathrm{cm})$ & $24.80 \pm 1.71$ & $24.25 \pm 2.02$ \\
Lower leg circumference $(\max )(\mathrm{cm})$ & $38.07 \pm 2.79$ & $37.46 \pm 1.99$ \\
Upper arm skinfolf $(\mathrm{mm})$ & $4.80 \pm 1.44$ & $5.29 \pm 1.12$ \\
Lower arm skinfold $(\mathrm{mm})$ & $5.46 \pm 1.33$ & $6.21 \pm .90$ \\
Thigh skinfold $(\mathrm{mm})$ & $9.69 \pm 3.52$ & $11.19 \pm 3.53$ \\
Calf skinfold $(\mathrm{mm})$ & $8.69 \pm 3.53$ & $7.98 \pm 1.58$ \\
Chest skinfold $(\mathrm{mm})$ & $7.76 \pm 3.46$ & $8.39 \pm 2.12$ \\
Abdomen skinfold $(\mathrm{mm})$ & $7.78 \pm 3.49$ & $8.38 \pm 1.94$ \\
\hline Note:MEAN &
\end{tabular}

Note: MEAN - arithmetic mean, SD - standard deviation 
On the basis of the results presented it was determined that there were no statistically significant differences in any tested variables. (Table 2).

Table 2. Independent Samples t-test

\begin{tabular}{|c|c|c|c|c|c|c|c|c|}
\hline & $\mathbf{F}$ & $T$ & Df & $\mathbf{P}$ & MD & SED & Min & Max \\
\hline Body height & 2.20 & -0.27 & 25 & 0.790 & -0.68 & 2.53 & -5.88 & 4.53 \\
\hline Bodyweight & 0.05 & -0.57 & 25 & 0.575 & -2.04 & 3.58 & -9.41 & 5.34 \\
\hline Elbow diameter & 0.56 & -1.44 & 25 & 0.164 & -1.82 & 1.27 & -4.42 & 0.79 \\
\hline Wrist diameter & 1.86 & 0.85 & 25 & 0.402 & 1.05 & 1.23 & -1.48 & 3.57 \\
\hline Knee diameter & 0.13 & 0.78 & 25 & 0.443 & 1.43 & 1.84 & -2.35 & 5.21 \\
\hline Ankle joint diameter & 0.84 & -0.35 & 25 & 0.728 & -0.38 & 1.10 & -2.64 & 1.87 \\
\hline Upper arm circumference (min) & 0.30 & 0.40 & 25 & 0.689 & 0.28 & 0.70 & -1.16 & 1.72 \\
\hline Upper arm circumference (max) & 0.01 & 0.38 & 25 & 0.706 & 0.27 & 0.72 & -1.21 & 1.76 \\
\hline Lower arm circumference (min) & 0.35 & 0.94 & 25 & 0.355 & 0.29 & 0.31 & -0.35 & 0.94 \\
\hline Lower arm circumference (max) & 0.79 & 0.53 & 25 & 0.604 & 0.29 & 0.54 & -0.83 & 1.41 \\
\hline Upper leg circumference (min) & 0.82 & -1.10 & 25 & 0.280 & -1.09 & 0.98 & -3.11 & 0.94 \\
\hline Upper leg circumference (max) & 0.03 & -0.74 & 25 & 0.465 & -0.99 & 1.34 & -3.75 & 1.76 \\
\hline Lower leg circumference (min) & 0.09 & 0.77 & 25 & 0.448 & 0.56 & 0.72 & -0.93 & 2.05 \\
\hline Lower leg circumference (max) & 0.63 & 0.66 & 25 & 0.515 & 0.61 & 0.93 & -1.30 & 2.52 \\
\hline Upper arm skinfolf & 0.79 & -0.98 & 25 & 0.336 & -0.49 & 0.49 & -1.51 & 0.53 \\
\hline Lower arm skinfold & 1.37 & -1.74 & 25 & 0.095 & -0.75 & 0.43 & -1.65 & 0.14 \\
\hline Thigh skinfold & 0.13 & -1.10 & 25 & 0.282 & -1.49 & 1.36 & -4.29 & 1.30 \\
\hline Calf skinfold & 3.07 & 0.69 & 25 & 0.499 & 0.71 & 1.04 & -1.43 & 2.85 \\
\hline Chest skinfold & 0.49 & -0.58 & 25 & 0.570 & -0.63 & 1.10 & -2.89 & 1.63 \\
\hline Abdomen skinfold & 0.79 & -0.55 & 25 & 0.586 & -0.59 & 1.08 & -2.81 & 1.62 \\
\hline
\end{tabular}

Note: F-value of Levene's test of equality of variances, t-value of t-test, df-number of degreeseof freedom, $p$-significance of two-tailed testing of arithmetic mean difference, MD-arithmetic mean difference, SED-standard error of diffeence, Min-the level of lower difference interval, Max-level of upper difference interval

\section{Discusion}

On the basis of the data obtained in this study, it has been established that they do not exist significant differences in anthropometric characteristics between basketball players and volleyball players who play in the high-quality junior leagues in Serbia. If we consider the facts that the average height of final four participants in 2016 FIBA U17 World Basketball Championship who played in Zaragoza in Spain, was 195.56 $\mathrm{cm}$, while the average height of the of all participants in CEV U17 Volleyball European Championship 2017 in Turkey was 189 centimeters, we can conclude that the players from Serbian basketball and volleyball junior premier league are tall enough and they do not lag behind the top European and World players, also that the selection process is quality conducted. However, this is not a surprise, as it is well known that the number of very tall subjects appears to be high in Dinaric Alpes area (Popović, Milašinović, Matić, Gardašević, \& Bjelica, 2016; Popović, Bjelica, Milašinović, \& Gardašević, 2016; Masanovic, 2018). Results related to measures of the skeleton transversal and body volume showed slightly higher values for basketball players for most diameters and circumference, and the exceptions are the diameter of the elbow and the ankle joint, and the maximum and minimum volume of the upper limbs in which greater values can be seen in the volleyball players. Considering the movement patterns in volleyball, bigger ankle joint diameter, and higher values of upper leg circumference ( $\max$ and $\mathrm{min}$ ) are expected primarily for the reason that volleyball is a sport which basic elements (smash and block) are repeated throughout the match. In order to achieve the superior performance of these elements, an athlete needs to have very strong legs, and a training for years inevitably must lead to the adaptation of the ankle joint, because it is a joint that carries more weight than all other joints during ordinary walk. These parameters demonstrate the quality of the work of the volleyball player and support previous research that indicates the great strength of the leg muscles among volleyball players (Oliveira, Valladares, Vaz, \& João, 2016; Ferreira Oliveira, Teixeira Vaz, Pastore, \& João, 2018). Subcutaneous adipose tissue showed significantly higher values for handball players in 5 out of 6 variables (upper arm skinfolf, lower arm skinfold, thigh skinfold, chest skinfold, abdomen skinfold). These results are in line with previous research (Smajic et al., 2015; Popovic et al., 2014), which is also logical because in research, basketball is recognized as an more aerobic sport then volleyball, in which running distance is greater (Masanovic, Vukcevic, \& Spajic, 2018; Spaic, Vukasevic, \& Masanovic, 2018). On the other hand, volleyball is played on a smaller pitch, the running distance during the match is much smaller which justifies somewhat higher value of the thickness of the skin folds (Vukotić, 2010).

Being a professional athlete requires a high level of preparation which, in addition to motor and functional abilities, must be supported by morphological characteristics that should correspond, through the perfect harmony, based on sport structure, to the rank of the competition and the sharacteristics of the player position, which differ within almost every sport branch (Vukasevic, Vukotic, \& Masanovic, 2018; Vukasevic, Spaic, Masanovic, 2018).

The aim of this research was to determine whether there is a difference, and the scope of it, in anthropometric characteristics between the junior basketball and volleyball players, and to characterize, accurately as possible, the morphological characteristics of subjects by measuring the individual body parts. 
Considering the movement patterns in basketball and volleyball, significant difference where not expected primarily for the reason that both sports are sports in which body height gives advantage in defence and attack because taller players have the ability to easily perform the basic elements of the game. In basketball, height helps players to save the ball and block the attack, and it is also advantageous because a higher player is closer to the ring, which means throwing the ball on the basket with less distance (Popovic, Akpinar, Jaksic, Matic, \& Bjelica, 2013), while in volleyball the height also helps to block the opponent's attack, and while the smash allows the attacker to hit the ball from a higher height and in that way gets a better angle for the attack and a greater possibility of choosing in which part of the opponent's field will place the ball (Laporta, Nikolaidis, Thomas, \& Afonso, 2015).

In transversal skeletal dimensionality, body volume and body mass, no significant difference was expected. It was more expected that under the influence of a specific type of training the organism would be adapted to what was expected of him, as was the case with the respondents of this study. Adaptation caused basketball players to have less fat tissue because running distance is greater (Masanovic \& Vukasevic, 2009; Masanovic, Vukotic, Popovic, \& Bjelica, 2018). On the other hand, volleyball players have a larger volume of upper leg and ankle joint diameter because of the constant repetition of the jump elements (Masanovic, Popovic, \& Bjelica, 2018).

Morphological characteristics of topclass basketball and volleyball players appear to be of great interest for some authors (Hooper, 1997; Gaurav, M. Singh, \& S. Singh, 2010; Ramos-Campo et al., 2014) with the interest of finding the best morphology somatotype for particular sports, competition levels and player positions as well. Comparison of anthropometrics should support coaches with better understanding of specific demands of certain sport, where particular morphology profile of an athlete, combined with motor and functional abilities, should express its full potential (Gusic et al. 2017).

\section{Acknowledgements}

There are no acknowledgements.

\section{Conflict of Interest}

The authors declare that there are no conflicts of interest.

Received: 30 October 2018 | Accepted: 1 December 2018 | Published: 25 January 2019

\section{References}

Bjelica, D., \& Fratrić, F. (2011). Sportski trening: teorija, metodika i dijagnostika. Nikšić: Fakultet za sport i fizičko vaspitanje.

Bjelica, D., Popović, S., i Gardašević, J. (2016). Modeli fizičke pripreme vrhunskih sportaša i doziranje opterećenja. Zbornik radova 14. godišnje međunarodne konferencije "Kondicijska priprema sportaša” (185-189), Zagreb: Udruga kondicijskih trenera Hrvatske.

Ferreira Oliveira, A.O.G., Teixeira Vaz, L.M., Pastore, J.C., \& João, P.V. (2018) Discriminate scoring skills and non-scoring skills according to results in the Brazilian men's volleyball SuperLeague. Montenegrin Journal of Sports Science and Medicine, 7(1), 73-79. doi: 10.26773/mjssm.180310

Gaurav, V., Singh, M., \& Singh, S. (2010). Anthropometric characteristics, somatotyping and body composition of volleyball and basketball players. Journal of Physical Education and Sports Management, 1(3), 28-32.

Hooper, D.M. (1997). Somatotype in high performance female netball players may influence player position and the incidence of lower limb and back injuries. British Journal of Sports Medicine, 31(3), 197-9.

Hurst, M., Loureiro, M., Valongo, B., Laporta, L., Nikolaidis, P., \& Afonso, J. (2017). Systemic Mapping of High-Level Women's Volleyball using Social Network Analysis: The Case of Attack Coverage, Freeball, and Downball. Montenegrin Journal of Sports Science and Medicine, 6(1), 57-64.
Laporta, L., Nikolaidis, P., Thomas, L., \& Afonso, J. (2015). The Importance of Loosely Systematized Game Phases in Sports: The Case of Attack Coverage Systems in High-Level Women's Volleyball. Montenegrin Journal of Sports Science and Medicine, 4(1), 19-24.

Masanovic, B. (2018). Standing height and its estimation utilizing arm spam and foot length measurements in dinaric alps population: a systematic review. Sport Mont, 16(2), 101-106. doi: 10.26773/smj.180619

Masanovic, B., \& Vukasevic, V. (2009). Differences of anthropometrical status on basketball and handball players in junior stature. Sport Mont, 6(18-1920), 576-582

Masanovic, B., Milosevic, Z., \& Corluka, M. (2018). Comparative Study of Anthropometric Measurement and Body Composition between Junior Handball and Volleyball Players from Serbian National League. International Journal of Applied Exercise Physiology, 7(4), 1-6.

Masanovic, B., Popovic, S., \& Bjelica, D. (2018). Comparative Study of Anthropometric Measurement and Body Composition Between Junior Soccer and Volleyball Players From National League. In Book of Abstracts 15th International Scientific Conference on Transformation Process in Sport "Sport Performance" (58), Podgorica: Montenegrin Sports Academy.

Masanovic, B., Spaic, S., \& Vukasevic, V. (2018). Comparative study of anthropometric measurement and body composition between different levels of competition. Journal of Anthropology of Sport and Physical Education, 2(4), 21-26. doi: 10.26773/jaspe.181004

Mašanović, B., Vukotić, M., Popović, S., \& Bjelica, D. (2018). Comparative study of anthropometric measurement and body composition between junior basketball and volleyball players from Serbian national league. In Proceedings World Congress of Performance Analysis of Sport XII (340). Opatija: International Society of Performance Analysis of Sport.

Monson, T. A., Brasil, M. F., \& Hlusko, L. J. (2018). Allometric variation in modern humans and the relationship between body proportions and elite athletic success. Journal of Anthropology of Sport and Physical Education, 2(3), 3-8. doi: 10.26773/jaspe.180701

Oliveira, A., Valladares, N., Vaz, L., \& João, P. (2016). Evaluation of Scoring Skills and Non Scoring Skills in the Brazilian SuperLeague Women's Volleyball. Montenegrin Journal of Sports Science and Medicine, 5(2), 25-31.

Pojskic, H., Separovic, V., Muratovic, M., \& Uzicanin, E. (2014). Morphological Differences of Elite Bosnian Basketball Players According to Team Position. Intional Journal of Morphoogy, 32(2), 690-694.

Popovic, S., Akpinar, S., Jaksic, D., Matic, R., \& Bjelica, D. (2013). Comparative Study of Anthropometric Measurement and Body Composition between Elite Soccer and Basketball Players. International Journal of Morphology, 31(2),461-7.

Popović, S., Bjelica, D., Jakšić, D., \& Hadžić, R. (2014). Comparative Study of Anthropometric Measurement and Body Composition between Elite Soccer and Volleyball Players. International Journal of Morphology, 32(1),267274

Popović, S., Bjelica, D., Milašinović, R., \& Gardašević, J. (2016). Body height and its estimation utilizing arm span measurements in male adolescents from northern region in Montenegro. In Book of Abstracts of 4th International Scientific Conference "Exercise and Quality of Life" (38), Novi Sad: Faculty of Sport and Physical Education.

Popović, S., Milašinović, R., Matić, R., Gardašević, J., \& Bjelica, D. (2016). Body height and its estimation utilizing arm span measurements in male adolescents from southern region in Montenegro. In Book of Abstracts of the 13th International Scientific Conference on Transformation Process in Sport "Sport Performance" (29-30), Podgorica: Montenegrin Sports Academy.

Rađa, A., Erceg, M., \& Grgantov, Z. (2016). Inter and Intra Positional Differences in Ball Kicking Between U-16 Croatian Soccer Players. Montenegrin Journal of Sports Science and Medicine, 5(2), 11-15.

Ramos-Campo, D.J., Martínez-Sánchez, F., Esteban-García, P., Rubio-Arias, J.A., Bores, C.A., Clemente-Suarez, V.J., \& Jiménez-Díaz, J.F. (2014). Body Composition Features in Different Playing Position of Professional Team Indoor Players: Basketball, Handball and Futsal. International Journal of Morphology, 32(4), 1316-24.

Smajic, M., Kuljanin, T., Savic, M., Korac, K., Vasic, G., \& Tomic, B. (2015). The influence of some anthropometric characteristics and motor abilities on agility in young female volleyball players. Sport Mont, 13(43-44-45), 169-175.

Spaic, S., Vukasevic, V., \& Masanovic, B. (2018). Differences in anthropometric characteristics among junior soccer and basketball players. Journal of Anthropology of Sport and Physical Education, 2(4), 89-92. doi: 10.26773/ jaspe. 181016

Stojanovic, M., Calleja-Gonzalez, J., Mikic, M., Madic, D., Drid, P., Vučković, I., \& Ostojić, S. (2016). Accuracy and Criterion-Related Validity of the 20-M Shuttle Run Test in Well-Trained Young Basketball Players. Montenegrin Journal of Sports Science and Medicine, 5(2), 5-10. 
Vukasevic, V., Spaic, S., \& Masanovic, B. (2018). Comparative study of anthropometric measurement and body composition between the basketbal player first and second league in Montenegro. Journal of Anthropology of Sport and Physical Education, 2(3),61-65. doi: 10.26773/jaspe.180711

Vukasevic, V., Vukotic, M., \& Masanovic, B. (2018). Comparative study of morphological characteristics and body composition between basketball players from second leagues in Montenegro and Serbia. Journal of Anthropology of Sport and Physical Education, 2(3),21-25. doi: 10.26773/jaspe.180704
Vukotic, M. (2018). Comparative analysis of antropmtric indicators of sportisis of different soprts guidance. In Book of Abstracts 15th International Scientific Conference on Transformation Process in Sport "Sport Performance" (75-76), Podgorica: Montenegrin Sports Academy.

Vukotić, M. (2010). Nivo morfoloških karakteristika, motoričkih i funkcionalnih sposobnosti sportista različitog sportskog usmjerenja. Neobjavljena magistarska teza. Nikšić: Fakultet za sport i fizičko vaspitanje. 